\title{
Hill drop sowing of soybean with different number of plants per hole
}

\section{Esmael Lopes dos Santos ${ }^{1}$ Victor José Agassi ${ }^{1}$ Alessandro Sartor Chicowski ${ }^{2}$ Julio Cezar Franchini ${ }^{3}$ Henrique Debiasi ${ }^{3}$ Alvadi Antonio Balbinot Junior ${ }^{3^{*}}$}

${ }^{1}$ Centro Universitário Filadélfia (Unifil), Londrina, PR, Brasil.

${ }^{2}$ Universidade Norte do Paraná (Unopar), Londrina, PR, Brasil.

${ }^{3}$ Embrapa Soja, Rodovia Carlos João Strass, 86001-970, Londrina, PR, Brasil. E-mail: alvadi.balbinot@embrapa.br. *Corresponding author.

ABSTRACT: In the last few cropping seasons, some soybean producers have tested the application of a hill drop sowing method, usually from three to four seeds every 30 to $40 \mathrm{~cm}$. However, there is a lack of information in the literature about the effect of this practice on soybean performance. Thus, the objective of this study was to evaluate the effect of a hill drop sowing with different number of plants per hole on soybean performance. The study was conducted in Londrina - PR, Brazil, during the 2013/14, 2014/15 and 2016/17 cropping seasons. The experiment was a randomized complete block design with four replications and a $2 x 5$ factorial scheme. The first factor consisted of two soybean cultivars, BRS 359RR and NK 7059RR analyzed in the first two cropping seasons and BRS 359RR and BRS 1010IPRO in the last cropping season. The second factor was constituted by five in-hill hole-spacing treatments (HS) (8, 16, 24, 32 and 40cm), with rows spaced 50cm apart. To maintain the same plant density in all treatments $\left(270,000\right.$ plants $\left.\mathrm{a}^{-1}\right)$, sowing was performed manually, being then thinned out. After thinning, the distribution was one plant per hole at HS8, 2 plants at HS16, 3 plants at HS24, 4 plants at HS32, and 5 plants at HS40. The agronomic performance of soybean in hill drop sowing with different number of plants per hole is similar to that of an equidistant distribution of plants. Key words: Glycine max L., spatial plant arrangement, spatial uniformity of plant distribution.

Agrupamento de plantas de soja na linha de semeadura com diferentes números de indivíduos por cova

RESUMO: Nas últimas safras, alguns produtores de soja vêm testando a semeadura agrupada de plantas na linha de semeadura, em geral de três a quatro sementes a cada 30 a $40 \mathrm{~cm}$. No entanto, há carência de informações na literatura sobre o efeito dessa prática no desempenho da cultura da soja. O objetivo desse trabalho foi avaliar o desempenho agronômico da soja em diferentes números de plantas por cova. $O$ trabalho foi conduzido em Londrina, PR, nas safras 2013/14, 2014/15 e 2016/17. O delineamento experimental foi em blocos completos casualizados, com quatro repetições e esquema fatorial $2 \times 5$. O primeiro fator foi constituído por duas cultivares de soja (BRS 359RR e NK 7059RR nas duas primeiras safras e BRS 359RR e BRS 1010IPRO na última safra) e o segundo por cinco espaçamentos entre plantas (EP) nas linhas de semeadura $(8,16,24,32$ e 40cm), sendo utilizado o espaçamento de 50cm entre linhas. Para manter a mesma densidade de plantas em todos os tratamentos (270.000 plantas $h^{-1}$ ), a semeadura foi realizada manualmente. Após o desbaste, a distribuição foi de uma planta por cova em EP8, duas plantas em EP16, três plantas em EP24, quatro plantas em EP32, cinco plantas em EP40. O desempenho agronômico da cultura da soja semeada com diferentes quantidades de plantas por cova é similar à distribuição equidistante de individuos na linha. Palavras-chave: Glycine max L., arranjo espacial de plantas, uniformidade espacial de distribuição de plantas.

\section{INTRODUCTION}

Alterations in the spatial arrangement of soybean plants, regarding row spacing, density and uniformity of plant distribution in a row determines intraspecific competition for water, light and nutrients, in addition to being able of influencing grain yield and yield components (BOARD, 2000; KUSS et al., 2008; PROCÓPIO et al., 2014; BALBINOT JUNIOR et al., 2015a). In the last decade, researches were carried out to verify the impact of new plant spatial arrangements on soybean agronomic performance, testing narrow row spacing (BALBINOT JUNIOR et al., 2015a), twin row configuration (PROCÓPIO et al., 2014) and crossed row lines (LIMA et al., 2012; PROCÓPIO et al., 2014; BALBINOT JUNOR et al., 2015b). These studies were conducted under several plant densities and environmental conditions. In general, changes in row spacing and plant density from 160 to 360 thousand soybean plants per hectare have little impact on grain yield, as long as the plants are evenly distributed throughout the area (DE LUCA e HUNGRIA, 2014; BALBINOT JUNIOR et al., 2015b; FERREIRA et al., 2016). Soybeans present a broad phenotypic plasticity to changes in spatial arrangement (FERREIRA et al., 2016). 
Otherwise, the effect of plant distribution uniformity along the row on crop performance, especially in early cultivars with high yield potential, has yet to be elucidated. In recent cropping seasons, some producers and manufacturers of sowing discs have tested the allocation of soybean seeds in a grouped arrangement - usually from three to four seeds every 30 to $40 \mathrm{~cm}$. Theoretically, such spatial arrangement may facilitate the emergence of plants in sealed surface soils, increasing grain yield as a function of a "border effect" between plant groups, besides facilitating canopy penetration of sprayed pesticides.

Conversely, an equidistant plant distribution in a row may reduce competition between soybean plants, enhancing grain yield. The objective of this study was to evaluate the effect of a hill drop sowing with different number of plants per hole on soybean performance.

\section{MATERIALS AND METHODS}

Three field experiments were conducted in the 2013/14, 2014/15 and 2016/17 cropping seasons, in Londrina, PR, Brazil ( $23^{\circ} 11^{\prime} \mathrm{S}, 51^{\circ} 11^{\prime} \mathrm{W}$ and $620 \mathrm{~m}$ above sea level, CfaKöpen-Geiger climate, Rhodic Eutrudox soil type, USDA or Latossolo Vermelho distrófico, Brazilian soil classification). In the first two cropping seasons, the experimental area presented the following attributes in the $0-20 \mathrm{~cm}$ layer: $15.8 \mathrm{~g} \mathrm{dm}^{-3}$ organic carbon; $4.8 \mathrm{pH}\left(\mathrm{CaCl}_{2}\right) ; 7.6 \mathrm{mg} \mathrm{dm}^{-3}$ $\mathrm{P}$ (Mehlich 1); $0.17 \mathrm{cmol} \mathrm{dm}^{-3} \mathrm{~K}$ exchanged; $3.3 \mathrm{cmol}$ $\mathrm{dm}^{-3} \mathrm{Ca}$ exchanged; e $1.4 \mathrm{cmol}_{\mathrm{c}} \mathrm{dm}^{-3} \mathrm{Mg}$ exchanged. In the third cropping season, the experimental area presented the following attributes in the $0-20 \mathrm{~cm}$ layer: $15.7 \mathrm{~g} \mathrm{dm}^{-3}$ organic carbon; $5.9 \mathrm{pH}\left(\mathrm{CaCl}_{2}\right) ; 20.3 \mathrm{mg}$ $\mathrm{dm}^{-3} \mathrm{P}$ (Mehlich 1); $0.56 \mathrm{cmol}_{\mathrm{c}} \mathrm{dm}^{-3} \mathrm{~K}$ exchanged; $5.2 \mathrm{cmol}_{\mathrm{c}} \mathrm{dm}^{-3} \mathrm{Ca}$ exchanged; e $2.6 \mathrm{cmol}_{\mathrm{c}} \mathrm{dm}^{-3} \mathrm{Mg}$ exchanged. The average values of air temperature and rainfall during the experiments are shown in figure 1 .

The experimental design was in randomized complete blocks with four replications and a $2 \times 5$ factorial scheme. The first factor consisted of two soybean cultivars, BRS 359RR and NK 7059RR planted in the first two cropping seasons $(2013 / 14$ and 2014/15), and BRS 359RR and BRS 1010IPRO in the third cropping season $(2016 / 17)$. The second factor was constituted by five in-hill hole-spacing treatmentsHS $(8,16,24,32$ and $40 \mathrm{~cm})$. Therefore, to maintain the same density in all treatments $\left(270,000\right.$ plants ha $\left.{ }^{-1}\right)$, sowing was performed manually, being subsequently thinned out. After thinning, numbers of plants per hole were 1, 2, 3, 4 and 5 for HS8, HS16, HS24, HS32 and HS40, respectively. Plots were constituted of four 5-m rows spaced $50 \mathrm{~cm}$ apart, using only the two central rows as useful area $\left(4 \mathrm{~m}^{2}\right)$. The evaluated soybean cultivars have indeterminate growth habit, belonging to the relative maturity groups 6.0, 6.1 and 6.1, respectively. These cultivars present characteristics common to most of the soybean genotypes currently grown in Brazil.

The experimental area was managed under a no-tillage system, being chemically desiccated 15 days before soybean sowing by spraying glyphosate $\left(1080 \mathrm{~g} \mathrm{ha}^{-1}\right)$. Sowing was carried out in the second half of October. A seed drill was used to open the sowing rows, applying $300 \mathrm{~kg} \mathrm{ha}^{-1}$ of $0-20-20\left(\mathrm{~N}-\mathrm{P}_{2} \mathrm{O}_{5}-\mathrm{K}_{2} \mathrm{O}\right)$ fertilizer. Soybean seeds were treated with Carboxina and Tiram - VitavaxThiram - 200SC ${ }^{\circledR}\left(300 \mathrm{~mL} 100 \mathrm{~kg}^{-}\right.$

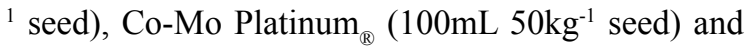
Bradyrhizobium elkanii- Gelfix $5^{\circledR}$ liquid inoculant (100mL $50 \mathrm{~kg}^{-1}$ of seeds). Control of pests, diseases and weeds was carried out according to the technical recommendations for the crop.

Grain yield was evaluated by harvesting the plants within the useful area of each plot, with the seed moisture being adjusted to $13 \%$. All plants present in the area were counted to check for significant differences among treatments. Twenty plants per plot were evaluated for height, number of branches per plant, number of pods per plant, number of grains per pod, thousand-grain mass (TGM) and apparent harvest index (AI). This rate was determined by dividing the grain mass by the shoot total mass of 20 plants harvested without senescent leaves. Protein content in the grains was determined using a $0.1-\mathrm{g}$ sample per plot, taken in triplicate, analyzed by the Kjeldahl method with copper sulfate as the catalyst. In the 2016/17 cropping season, neither AI nor protein content was assessed.

Data were submitted to test of normality (Shapiro-Wilks) and homogeneity of variance (Hartley) for each trial, followed by analysis of variance (ANOVA) with application of $F$ test $(p \leq 0.05)$ and means comparison by Tukey test $(\mathrm{p} \leq 0.05)$.

\section{RESULTS AND DISCUTION}

In the 2013/14 cropping season there was a severe water deficit during the flowering and grain filling period. Conversely, in the 2014/15 and 2016/17 the water availability was adequate to the crop (Figure 1). There was no difference regarding plant density among treatments in all evaluated cropping seasons, being of around 270 thousand plants $\mathrm{ha}^{-1}$. For all evaluated variables, there was no significant effect of the interaction between cultivars and hill-drop patterns. Thus, the data will be presented considering the average between two 


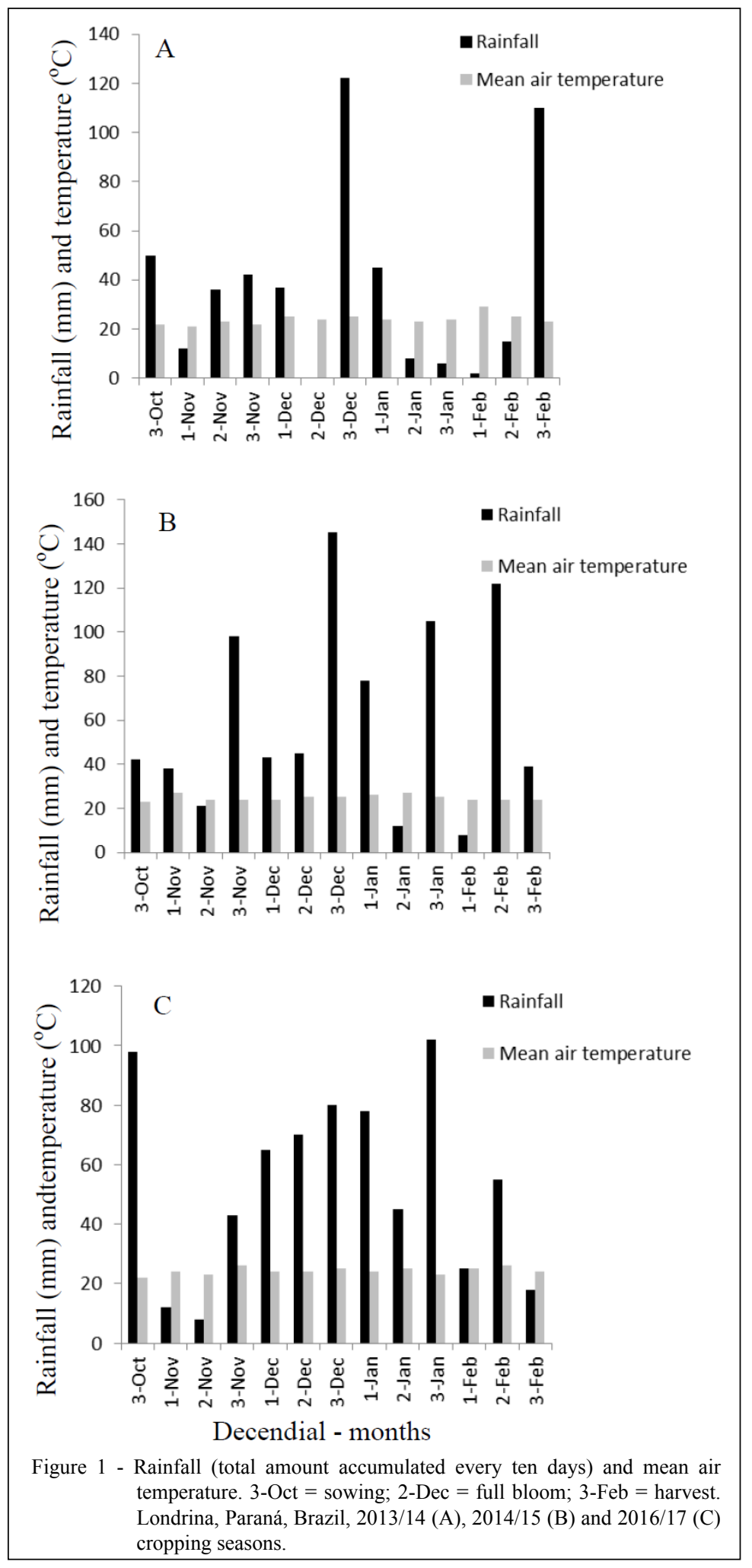

cultivars. In the 2013/14 and 2016/17 cropping seasons, the hill-drop patterns showed no effect on plant height; however, in the 2014/15 season, the lowest plant density per hole - one plant each 8 row $\mathrm{cm}$ - presented shorter plants in relation to the treatments HS24 and HS32 (Table 1). Under a poor lightning, dense plant stands are 
Table 1 - Plant height and number of branches per plant in different hill-drop patterns of plants within a row (average of two cultivars). Londrina, Paraná, Brazil, 2013/14, 2014/15 and 2016/17 cropping seasons.

\begin{tabular}{|c|c|c|}
\hline Spacing between hills within a row $(\mathrm{cm}) /$ number of plants per hill $^{1}$ & Plant height $(\mathrm{cm})$ & Number of branches per plant \\
\hline \multicolumn{3}{|c|}{-------------------------------------------------------------------2013/14 cropping season----------------------------------------------------------------- } \\
\hline $8 / 1$ (HS8) & $72.5 \mathrm{~ns}$ & $2.22 \mathrm{a}^{2}$ \\
\hline 16/2 (HS16) & 72.4 & $1.22 \mathrm{~b}$ \\
\hline 24/3 (HS24) & 73.4 & $1.28 \mathrm{~b}$ \\
\hline 32/4 (HS32) & 71.0 & $1.22 \mathrm{~b}$ \\
\hline 40/5 (HS40) & 75.1 & $1.58 \mathrm{~b}$ \\
\hline $\mathrm{CV}(\%)$ & 8.0 & 22.3 \\
\hline \multicolumn{3}{|c|}{ 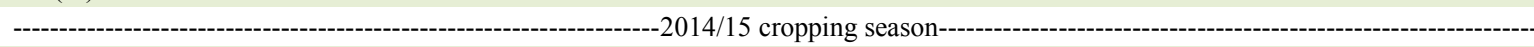 } \\
\hline $8 / 1$ (HS8) & $78.2 \mathrm{~b}$ & $3.50 \mathrm{~ns}$ \\
\hline 16/2 (HS16) & $84.2 \mathrm{ab}$ & 3.60 \\
\hline 24/3 (HS24) & $88.1 \mathrm{a}$ & 3.55 \\
\hline $32 / 4(\mathrm{HS} 32)$ & $88.8 \mathrm{a}$ & 3.50 \\
\hline $40 / 5(\mathrm{HS} 40)$ & $84.2 \mathrm{ab}$ & 3.33 \\
\hline $\mathrm{CV}(\%)$ & 6.0 & 17.8 \\
\hline \multicolumn{3}{|c|}{----------------------------------------------------------------'2016/17 cropping season--------------------------------------------------------------- } \\
\hline 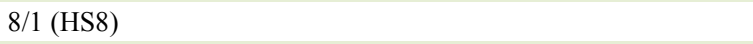 & $94.3 \mathrm{~ns}$ & $3.16 \mathrm{~ns}$ \\
\hline 16/2 (HS16) & 96.0 & 3.20 \\
\hline 24/3 (HS24) & 91.9 & 3.07 \\
\hline $32 / 4(\mathrm{HS} 32)$ & 91.8 & 2.80 \\
\hline 40/5 (HS40) & 88.1 & 3.08 \\
\hline $\mathrm{CV}(\%)$ & 10.8 & 21.2 \\
\hline
\end{tabular}

${ }^{1}$ Number of plants per hill in $50 \mathrm{~cm}$ row spacing with 270,000 plants ha ${ }^{-1} .{ }^{2}$ Means followed by the same letter in the column do not differ at $5 \%$ probability, Tukey test. $\mathrm{ns}=$ not significant differences. $\mathrm{CV}=$ coefficient of variation.

likely to reduce light quality intercepted by plants at the beginning of crop cycle, thus stimulating height growth (BALLARÉ \& CASAL, 2000). However, these plant height differences verified here have little relevance since they were of small range. While studying holespacing, plant density and crossed rows, BALBINOT JUNIOR et al. (2015a) also observed a little effect of soybean spatial arrangements on plant height.

In the 2013/14 cropping season, HS8 promoted a greater branching density than the other treatments (Table 1). Conversely in the 2014/15 and 2016/17 cropping seasons, there was no effect of the hill-drop patterns on the number of branches per plant, being substantially superior values in 2013/14. This was probably due to a more favorable climate for plant growth observed in the last two cropping seasons (Figure 1). This result suggests that, under conditions where plant growth is favored, the distribution of the plants in rows has little impact on the branching ratio. Differently, BALBINOT JUNIOR et al. (2015a and 2015b) verified that plant density affect the branching to a high degree; however, the pattern of plant arrangement has little effect on the number of branches per plant and on the role of branches in grain production.
In all three cropping seasons, the hill-drop patterns had no impact on the number of pods per plant, the number of grains per pod and the thousandgrain mass (Table 2). Since there was no effect of the treatments on soybean yield components, grain yield had no influence from the plant spatial distributions along rows. In general, HS8 promoted no further benefits to soybean plants if compared to the other patterns. Due to the high phenotypic plasticity of soybeans (DE LUCA et al., 2014; LEE et al., 2008; PROCÓPIO et al., 2013; PETTER et al., 2016), the agronomic responses to the in-hill hole-spacing patterns were insignificant. Despite of the differences in morphophysiological characteristics between maize and soybeans, neither one nor the other is harmed by the clustering of plants within a row, in terms of grain yield (RIZZARDI \& PIRES, 1996). In this context, it is easier for the farmers to use the machines currently available.

Likewise, the hill-drop of plants caused no changes in the apparent harvest index of soybeans (Table 3). BALBINOT JUNIOR et al. (2015a) verified no effect of soybean plant arrangement on 
Table 2 - Number of pods per plant (NPP), number of grains per pod (NGP), thousand grain mass (TGM) and grain yield in different hilldrop patterns of plants within a row (average of two cultivars). Londrina, Paraná, Brazil, 2013/14, 2014/15 and 2016/17 cropping seasons.

\begin{tabular}{|c|c|c|c|c|}
\hline Spacing between hills within a row $(\mathrm{cm}) /$ number of plants per hill ${ }^{1}$ & NPP & NGP & TGM $(g)$ & Yield $\left(\mathrm{kg} \mathrm{ha}^{-1}\right)$ \\
\hline \multicolumn{5}{|c|}{ 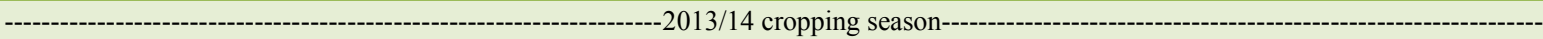 } \\
\hline $8 / 1$ (HS8) & $29.3 \mathrm{~ns}$ & $2.34 \mathrm{~ns}$ & $113 \mathrm{~ns}$ & $2,133 \mathrm{~ns}$ \\
\hline $16 / 2$ (HS16) & 26.2 & 2.00 & 123 & 2,273 \\
\hline $24 / 3$ (HS24) & 25.1 & 2.05 & 131 & 2,212 \\
\hline 32 / 4 (HS32) & 24.8 & 2.09 & 116 & 2,511 \\
\hline 40 / 5 (HS40) & 25.8 & 2.13 & 126 & 2,564 \\
\hline $\mathrm{CV}(\%)$ & 26.6 & 13.0 & 18.5 & 18.8 \\
\hline \multicolumn{5}{|c|}{ 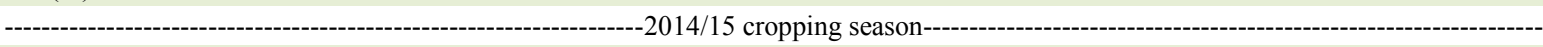 } \\
\hline $8 / 1$ (HS8) & $43.2 \mathrm{~ns}$ & $2.13 \mathrm{~ns}$ & $127 \mathrm{~ns}$ & $2,866 \mathrm{~ns}$ \\
\hline $16 / 2$ (HS16) & 49.0 & 2.13 & 120 & 2,972 \\
\hline 24 / 3 (HS24) & 40.7 & 2.32 & 117 & 2,675 \\
\hline 32 / 4 (HS32) & 43.8 & 2.11 & 136 & 2,721 \\
\hline 40 / 5 (HS40) & 45.4 & 1.97 & 125 & 2,647 \\
\hline $\mathrm{CV}(\%)$ & 18.5 & 13.1 & 12.4 & 10.3 \\
\hline \multicolumn{5}{|c|}{ 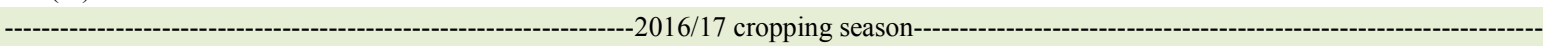 } \\
\hline $8 / 1$ (HS8) & $46.7 \mathrm{~ns}$ & $2.11 \mathrm{~ns}$ & $153 \mathrm{~ns}$ & $4,228 \mathrm{~ns}$ \\
\hline $16 / 2$ (HS16) & 47.1 & 2.10 & 152 & 4,265 \\
\hline 24 / 3 (HS24) & 47.4 & 2.01 & 159 & 4,541 \\
\hline 32 / 4 (HS32) & 47.8 & 2.02 & 157 & 4,244 \\
\hline 40 / 5 (HS40) & 44.9 & 2.12 & 153 & 4,330 \\
\hline $\mathrm{CV}(\%)$ & 15.7 & 6.6 & 13.8 & 13.1 \\
\hline
\end{tabular}

${ }^{1}$ Number of plants per hill in $50 \mathrm{~cm}$ row spacing with 270,000 plants ha ${ }^{-1} \mathrm{~ns}=$ not significant differences. $\mathrm{CV}=$ coefficient of variation.

the phytomass partitioning of canopies vegetative structures and grains. In addition, the protein content in grains was not affected by the treatments (Table 3 ).
According to FERREIRA et al. (2016), the spatial arrangement of soybean plants has no impact on the oil and protein contents in grains.

Table 3 - Apparent harvest index (AI) and grain protein content in different hill-drop patterns of plants within a row (average of two cultivars). Londrina, Paraná, Brazil, 2013/14, 2014/15 and 2016/17 cropping seasons.

\begin{tabular}{|c|c|c|}
\hline Spacing between hills within a row $(\mathrm{cm}) /$ number of plants per hill ${ }^{1}$ & AI & Protein $(\%)$ \\
\hline \multicolumn{3}{|c|}{ 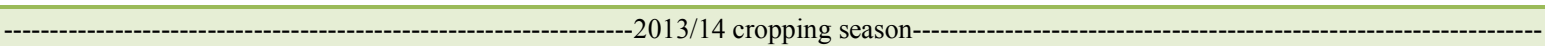 } \\
\hline $8 / 1(\mathrm{HS} 8)$ & $0.49 \mathrm{~ns}$ & $38.2 \mathrm{~ns}$ \\
\hline 16/2 (HS16) & 0.54 & 38.6 \\
\hline 24/3 (HS24) & 0.54 & 39.6 \\
\hline 32/4 (HS32) & 0.53 & 38.3 \\
\hline 40/5 (HS40) & 0.53 & 39.3 \\
\hline CV $(\%)$ & 11.4 & 2.9 \\
\hline \multicolumn{3}{|c|}{ - } \\
\hline $8 / 1(\mathrm{HS} 8)$ & $0.51 \mathrm{~ns}$ & $38.8 \mathrm{~ns}$ \\
\hline 16/2 (HS16) & 0.50 & 38.2 \\
\hline 24/3 (HS24) & 0.50 & 34.9 \\
\hline 32/4 (HS32) & 0.49 & 37.1 \\
\hline 40/5 (HS40) & 0.50 & 38.4 \\
\hline CV $(\%)$ & 5.6 & 7.4 \\
\hline
\end{tabular}

${ }^{1}$ Number of plants per hill in $50 \mathrm{~cm}$ row spacing with 270,000 plants ha ${ }^{-1} \mathrm{~ns}=$ not significant differences. $\mathrm{CV}=$ coefficient of variation. 


\section{CONCLUSION}

The agronomic performance of soybean in hilldrop sowing with different number of plants per hole is similar to that of an equidistant distribution of plants.

\section{ACKNOWLEDGMENTS}

To Conselho Nacional de Desenvolvimento Científico e Tecnológico ( $\mathrm{CNPq})$ for granting the scholarships of Productivity in Technology Development and Innovative Extension for the last author (304752/2016-9).

\section{DECLARATION OF CONFLICT OF INTEREST}

The authors declared no potential conflicts of interest with respect to the research, authorship, and/or publication of this article.

\section{REFERENCES}

BALBINOT JUNIOR, A.A. et al. Narrow row and crossed lines associated with different plant densities of soybean. Semina: Ciências Agrárias, v.36, p.2975-2984, 2015a. Available from: <http://www. uel.br/revistas/uel/index.php/semagrarias/article/view/16273/17148>. Accessed: may. 22, 2017. doi: 10.5433/1679-0359.2015v36n5p2977.

BALBINOT JUNIOR., A.A. et al. Sowing in crossed rows in soybean cultivars with determinate growth habit. Semina: Ciências Agrárias, v.36, p.1215-1226, 2015b. Available from: <http://www.uel.br/ revistas/uel/index.php/semagrarias/article/viewFile/14900/16334>. Accessed: may. 22, 2017. doi: 10.5433/1679-0359.2015v36n3p1215.

BALLARÉ, C.L.; CASAL J.J. Light signals perceived by crop and weed plants. Field Crops Research, v.67, p.149-160, 2000. Available from: <http://www.sciencedirect.com/science/article/pii/ S0378429000000903 >. Accessed: may. 22, 2017. doi: 10.1016/503784290(00)00090-3.

BOARD, J. Light interception efficiency and light quality affect yield compensation of soybean at low plant populations. Crop Science, v.40, p.1285-1294, 2000. Available from: $<\mathrm{https}: / / \mathrm{dl}$. sciencesocieties. org/publications/cs/abstracts/40/5/1285>. Accessed: may. 22, 2017. doi: $10.2135 /$ cropsci2000.4051285x.

DE LUCA, M.J. et al. Feasibility of lowering soybean planting density without compromising nitrogen fixation and yield. Agronomy Journal, v.106, p.2118-2124, 2014. Available from: <https:// dl.sciencesocieties.org/publications/aj/pdfs/106/6/2118>. Accessed: may. 22, 2017. doi: 10.2134/agronj14.0234.
DE LUCA, M.J.; HUNGRIA, M. Plant densities and modulation of symbiotic nitrogen fixation in soybean. Scientia Agricola, v.71, p.181-187, 2014. Available from: <http://www.scielo. br/scielo.php?pid=S0103-90162014000300002\&script=sci arttext>. Accessed: may. 22, 2017. doi: 10.1590/S010390162014000300002 .

FERREIRA, A.S. et al. Plant density and mineral nitrogen fertilization influencing yield, yield components and concentration of oil and protein in soybean grains. Bragantia, Campinas, v.75, p.310-316, 2016. Available from: $<$ http://www.scielo.br/scielo.php?pid=S000687052016000300362\&script=sci_arttext>. Accessed: may. 22, 2017. doi: 10.1590/1678-4499.479.

KUSS, R.C.R. et al. Plant population and irrigation management strategies in the soybean tillage. Ciência Rural, v.38, p.1133-1137, 2008. Available from: $<$ http://www.scielo.br/scielo.php?script=sci_ar ttext\&pid=S0103-84782008000400036>. Accessed: may. 22, 2017. doi: $10.1590 / \mathrm{S} 0103-84782008000400036$.

LEE, C.D. et al. Soybean response to plant population at early and late planting dates in the Mid-South. Agronomy Journal, v.100, p.971976, 2008.

LIMA, S.F. et al. Effect of sowing in crossed lines on grain yield and the severity of Asian soybean rust. Bioscience Journal, Uberlândia, v.28, p.954-962, 2012. Available from: $<$ http://www.seer.ufu.br/index. $\mathrm{php} /$ biosciencejournal/article/view/13960/11106>. Accessed: may. 22, 2017.

PETTER, F.A. et al. Does high seeding density increase soybean productivity? Photosynthetically active radiation responses. Bragantia, v.75, p.173-183, 2016. Available from: <https://www.researchgate.net/ profile/Alan_Zuffo/publication/301572729_Elevada_densidade_de semeadura aumenta a produtividade da soja Respostas da radiacao fotossinteticamente_ativa/links/572d02 dd08aeb1c73d11 b6 de.pdf $\$$. Accessed: may. 22, 2017. doi: 0.1590/1678-4499.447.

PROCÓPIO, S.O. et al. Sowing in crossed rows in a soybean cultivar with indeterminate growth habit. Revista de Ciências Agrárias/ Amazonian Journal of Agricultural and Environmental Sciences, v.56, p.319-325, 2013.

PROCÓPIO, S.O. et al. Sowing in twin or narrow rows in soybean crop. Agro@mbiente online, v.8, p.212-221, 2014. Available from: $<$ https://ainfo.cnptia.embrapa.br/digital/bitstream/item/110175/1/ Semeadura-em-fileira-dupla-e-espacamento-reduzido-na-culturada-soja.pdf $>$. Accessed: may. 22, 2017. doi: 10.1590/1678-4499.479.

RIZZARDI, M.A.; PIRES, J.L. Response of corn cultivars to planting pattern in row sowing, with and without weed control. Ciência Rural, v.26, p.13-17, 1996. Available from: <http://www.scielo.br/scielo. php?pid=S0103-84781996000100003\&script $=$ sci_abstract\&tlng $=$ pt $>$. Accessed: may. 22, 2017. doi: 10.1590/S0103-84781996000100003. 